University of Nebraska - Lincoln

DigitalCommons@University of Nebraska - Lincoln

Faculty Publications: Department of Entomology

$1-18-2019$

Residues of thiamethoxam and mefenoxam in vegetative and

floral tissue of soybean at the early reproductive stage resulting

from seed treatments

\author{
Carolina Camargo \\ Daniel D. Snow \\ Sathaporn Onanong \\ Thomas Hunt \\ Blair Siegfried
}

Follow this and additional works at: https://digitalcommons.unl.edu/entomologyfacpub

Part of the Agricultural Economics Commons, Apiculture Commons, Entomology Commons, Environmental Health Commons, Environmental Health and Protection Commons, Environmental Indicators and Impact Assessment Commons, Environmental Monitoring Commons, Other Environmental Sciences Commons, Other Pharmacology, Toxicology and Environmental Health Commons, and the Toxicology Commons

This Article is brought to you for free and open access by the Entomology, Department of at DigitalCommons@University of Nebraska - Lincoln. It has been accepted for inclusion in Faculty Publications: Department of Entomology by an authorized administrator of DigitalCommons@University of Nebraska - Lincoln. 


\title{
Residues of thiamethoxam and mefenoxam in vegetative and floral tissue of soybean at the early reproductive stage resulting from seed treatments
}

\author{
Carolina Camargo, ${ }^{1,2}$ Daniel D. Snow, ${ }^{3}$ \\ Sathaporn Onanong, ${ }^{3}$ Thomas E. Hunt, ${ }^{4}$ \\ Blair D. Siegfried ${ }^{5}$
}

1 Department of Entomology, University of Nebraska-Lincoln, Lincoln, NE, 103 Entomology Hall, 68583, USA

2 Present address: Max Planck-Universidad de Antioquia Tandem Group Mosquito Reproductive Biology Ruta N, Torre A, Laboratorio 4-166 Calle 67, No 52-20, Medellín, 050010, Colombia. (Corresponding author: email carolinacamargo01@gmail.com ),

3 Water Sciences Laboratory, Nebraska Water Center, University of Nebraska-Lincoln Water Sciences Laboratory, 1840 N. 37th Street. Lincoln, NE, 68583-0844, USA; dsnow1@unl. edu (D.D. Snow), sonanong2@unl.edu (S. Onanong)

4 Department of Entomology University of Nebraska-Lincoln, Haskell Agricultural Laboratory, 57905866 Road, Concord, NE, 68728, USA thunt2@unl.edu (T.E. Hunt), 5 Department of Entomology and Nematology, University of Florida, 1881 Natural Area Drive, Steinmetz Hall, Gainesville, FL, 32611, USA; bsiegfried1@ufl.edu (B.D. Siegfried).

\begin{abstract}
Thiamethoxam with mefenoxam is the most widely used neonicotinoid insecticide/ fungicide mixture applied to soybean (Glycine max [L]) as seed treatments. Based on the systemic nature of thiamethoxam and mefenoxam, residues of this insecticide/fungicide mixture may be present in soybean vegetative and floral tissue and
\end{abstract}

Published in Crop Protection 119 (2019), pp 134-140.

doi 10.1016/j.cropro.2019.01.019

Copyright (c) 2019 Elsevier Ltd. Used by permission.

Submitted 15 December 2017; revised 13 January 2019; accepted 17 January 2019;

published 18 January 2019. 
negatively impact beneficial insects. Although neonicotinoids are often applied in combination with systemic fungicides, the research on ecological risks of neonicotinoids has been focused on the analysis of these compounds without considering their interaction with other agrochemicals. The objective of this study was to identify the concentration of thiamethoxam and mefenoxam in soybean flowers and leaves during early reproductive soybean stages. A field experiment with three treatments: a thiamethoxam-mefenoxam combination, thiamethoxam only, and untreated seeds, was conducted. Flowers were collected during early reproductive soybean stages R1-R2 at different locations in Nebraska during two years. Quantification of the pesticides in floral tissue was conducted using a modification of the QuEChErs extraction method and HPLC-MS/MS analysis. Mean concentrations of thiamethoxam and mefenoxam in floral and vegetative tissue were extremely low or not detected although trace levels of thiamethoxam were higher in floral tissues from seed treatments relative to the control. The only residue consistently detected above the method detection limit among plants grown from thiamethoxam treated seeds was the thiamethoxiam metabolite, clothianidin. Results from this study provide important baseline information to estimate the window of activity for this compound in soybean in the North Central Region of the United States.

Keywords: Neonicotinoids, Soybean reproductive stages, Mefenoxam, Residues

\section{Introduction}

The use of systemic pesticides has gained considerable attention due to the potential risk that these compounds pose to pollinators, insect natural enemies, and other non-target organisms living both above and below ground (Douglas and Tooker, 2015; Krupke et al., 2012; Pisa et al., 2015). Systemic pesticides must persist in the plant long enough to achieve control of above and below ground pests; therefore, they may contaminate food sources of beneficial insects, such as insect prey, pollen, nectar, and leaf guttation (Bonmatin et al., 2015; Girolami et al., 2009; Krupke et al., 2012; Pisa et al., 2015; Seagraves and Lundgren, 2012). Thiamethoxam and mefenoxam are two of the most widely used systemic pesticides in soybean, Glycine max $(\mathrm{L})$, seed treatments in the U.S. (Cox and Cherney, 2011; Cox et al., 2008; Gaspar et al., 2015). The fate of these and other systemic pesticides in floral tissues is extremely important due to their potential impact on non-target insects that utilize pollen and nectar resources (Bonmatin et al., 2015).

Thiamethoxam is a water-soluble compound $\left(4.1 \mathrm{~g} \mathrm{l}^{-1}\right.$ at $\left.20^{\circ} \mathrm{C}\right)$ which allows the uptake and translocation of the active ingredient through the vascular system of the plants (Maienfisch et al., 2001). 
Importantly, thiamethoxam can be metabolized by plants to the equally toxic clothianidin (Jeschke et al., 2011) which has been detected in plant tissues grown from thiamehtoxam treated seeds including soybean plants (Tietjen et al., 2017). Mefenoxam (also called $\mathrm{R}$-metalaxyl) is the $R$-enantiomer of metalaxyl and a commonly used fungicide in seed treatments (Monkiedje et al., 2007). This fungicide is highly systemic and water soluble $\left(26 \mathrm{~g} \mathrm{l}^{-1}\right.$ at $\left.20^{\circ} \mathrm{C}\right)$ and one of the most frequently applied fungicides used for crop protection worldwide (Triantafyllidis et al., 2012). The broad-spectrum activity and highly systemic properties of thiamethoxam and mefenoxam have contributed to the success and widespread use of these compounds in seed treatment applications (Simon-Delso et al., 2015). However, the systemic properties of these pesticides have also caused concern during the last decade because they can be translocated to floral tissues that serve as a food source for pollinators and other beneficial insects (van der Sluijs et al., 2015).

Residues of neonicotinoid insecticides have been identified in leaves and flowers of seed treated plants for several crops including canola, corn, cotton, and sunflower (Bonmatin et al., 2015; Bredeson and Lundgren, 2015; Krupke et al., 2012; Stewart et al., 2014; Stoner and Eitzer, 2012; Xu et al., 2016). Residues of thiamethoxam have been identified at $\sim 5 \mathrm{ng} / \mathrm{g}$ in mature leaves at early reproductive stages of soybean development (Magalhaes et al., 2009). However, there is limited information on the translocation of neonicotinoids and other systemic pesticides to soybean flowers. Stewart et al. (2014) characterized the translocation of neonicotinoids in soybean in the southern U.S., and reported very low concentrations in soybean flowers. Information is limited for translocation of systemic products in northern soybean growing regions of the U.S. where more than $80 \%$ of the U.S. soybean is grown. The use of early maturity varieties in northern states versus southern states may increase the probability of finding residues in soybean flowers in northern production areas (Pedersen and Elbert, 2004). Early maturating varieties exhibit faster development from planting to flowering (Pedersen and Lauer, 2004), possibly reducing the time for metabolism of neonicotinoids applied as seed treatment in plant tissue and increasing the probability of translocation to reproductive tissues.

For mefenoxam, information on residues and translocation in the plant is also very limited (Monkiedje and Spiteller, 2005). Although 
several authors report the systemic movement of mefenoxam and metalaxyl in plants, few of those studies quantify the active ingredient in plant tissues and its persistence over time (Monkiedje et al., 2007; Singh et al., 1986; Sukul, 2000; Wilson et al., 2001). Mefenoxam and metalaxyl are highly water-soluble compounds and have the potential to move to vegetative tissues as well as pollen and nectar of flowers. Krupke et al. (2012) reported residues of metalaxyl in pollen of seed treated corn at a concentration of $3.1 \mathrm{ng} / \mathrm{g}$. Although fungicides in seed treatments are not acutely toxic to insects, they may have synergistic or additive effects when combined with neonicotinoids and should be considered when assessing the risk of seed treatments to non-target insects (Krupke et al., 2012).

Quantifying the concentrations of thiamethoxam, the thiamethoxam metabolite clothianidin and mefenoxam in soybean plants at reproductive stages is important to identify the window of activity of these products and the possible risks that these products might have on non-target organisms. The objective of this study was to quantify the concentrations of thiamethoxam, the active metabolite, clothianidin, and mefenoxam in select vegetative stages and flowers of soybean plants grown from treated seeds.

\section{Methodology}

\subsection{Thiamethoxam and mefenoxam in soybean flowers}

The experiment was conducted during two consecutive soybean growing seasons. In 2013, research plots were located at the University of Nebraska Northeast Research and Extension Center, Haskell Agricultural Laboratory in Concord, NE (Latitude 42 $23^{\prime} 2.38^{\prime \prime} \mathrm{N}$; Longitude $\left.96^{\circ} 56^{\prime} 29.14^{\prime \prime} \mathrm{W}\right)$. Planting at the Concord site was conducted on June 11. In 2014, research plots were located in two different fields, one at the University of Nebraska-Lincoln Agricultural Research and Development Center at Ithaca, NE (Latitude $41^{\circ} 9^{\prime} 54.49^{\prime \prime} \mathrm{N}$; Longitude $\left.96^{\circ} 24^{\prime} 50.45^{\prime \prime} \mathrm{W}\right)$, and the second at the University of Nebraska-Lincoln East Campus field plots maintained by the Department of Agronomy and Horticulture, Lincoln, NE (Latitude $40^{\circ} 50^{\prime} 9.93^{\prime \prime} \mathrm{N}$; Longitude, $\left.96^{\circ} 39^{\prime} 44.95^{\prime \prime} \mathrm{W}\right)$. Planting dates were May 30 and June 1 for the Ithaca and Lincoln sites, respectively. 
The design was a randomized complete block, with three treatments and three replications in each field. Treatments consisted of: 1) thiamethoxam alone at $0.0756 \mathrm{mg}$ ai/seed, 2) thiamethoxammefenoxam at 0.0756 and $0.0113 \mathrm{mg}$ ai/seed, respectively and 3) untreated seeds. In both years, group 3 maturity (NK S30-E) seeds were custom treated by Syngenta Crop Protection, Stanton, MN. Treatment plots consisted of 8 rows planted $0.76 \mathrm{~m}$ between rows and $5.2 \mathrm{~m}$ in length with $1.52 \mathrm{~m}$ between replications. Planting density was 345,947 seeds/hectare.

Destructive sampling of soybean plants was conducted at reproductive stage $\mathrm{R} 1$ and 45 days after planting in 2013 and at 38 and 39 days after planting in 2014. A total of $\sim 25 \mathrm{~g}$ of flowers were randomly collected from plants in the middle four rows and at least 60 $\mathrm{cm}$ from each end of the plot. Flowers were collected from all nodes of the plant. Flowers were cut at the calix base and bagged for each plot. Collected flowers were kept in plastic bags in a plastic cooler with ice during transport. Samples were stored at $-80^{\circ} \mathrm{C}$ until further analysis. Each collected flower included the lateral bract, calix lobe, standard petals, wing petals, keel, ovary, stigma, and stamens.

\subsection{Thiamethoxam and mefenoxam in early reproductive stage soybean leaves}

Collection of vegetative tissue was conducted in 2014 and 2015 with fields located at the University of Nebraska-Lincoln East Campus in both years as previously described. Planting dates were May 30 and June 11 in 2014 and 2015, respectively. Because neonicotinoids have been reported to occur at low concentrations in foliage 30 and 40 days after planting (Magalhaes et al., 2009), leaves from the entire plant were pooled for further analysis. Plants were randomly selected from R1 stage plants from the two middle rows of each plot 35 days after planting during 2014 and 37 days after planting during 2015. All the leaves were collected except cotyledons and unopened trifoliates. Samples were kept on ice during transport and transferred to a $-20{ }^{\circ} \mathrm{C}$ freezer for storage upon returning from the field.

Although the translocation of metalaxyl has been previously reported for soybean (Gupta et al., 1985), there are no studies in soybean evaluating the translocation of other phenylamide fungicides, such as mefenoxam. Therefore, to verify the translocation of 
mefenoxam into soybean vegetative tissue from the applied rate, one sample of leaves from five plants in the mixture treatment (thiamethoxam + mefenoxam) was collected at 18 days after planting (V2).

\subsection{Pesticide extraction}

Individual standard stock solutions of thiamethoxam (99.5\% A.I), clothianidin (99.4\% A.I), mefenoxam (99.9\%), internal standards $\mathrm{C}_{3}$ - thiamethoxam, $\mathrm{C}_{3-}$ clothianidin, and $\mathrm{C}_{6-}$ mefenoxam, and the surrogate ter-

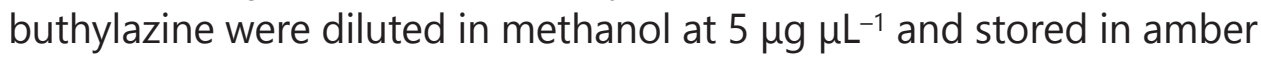
glass flasks at $-20^{\circ} \mathrm{C}$. Calibration solutions were prepared from the stock solutions over a concentration range of $1-125 \mu \mathrm{g} \mathrm{L}^{-1}$, of target compounds and $100 \mu \mathrm{g} \mathrm{L}^{-1}$ for internal standards.

The sample preparation procedure was based on the modified QuEChERS methodology (Pohorecka et al., 2012). A total of $10 \mathrm{~g}$ of plant material were used for each extraction. Flower samples included the petals, wing petals, keel, ovary, stigma, and stamens. Plant tissues were ground using a mortar and pestle in liquid nitrogen until a fine powder was obtained. Samples were fortified with $60 \mathrm{ng}$ of surrogate and placed in a $50 \mathrm{ml}$ centrifuge tube with $30 \mathrm{ml}$ of acetonitrile as an extraction reagent. The tube was shaken overnight using a multipurpose rotator and centrifuged at $5000 \mathrm{rpm}$ for $5 \mathrm{~min}$. A total of $15 \mathrm{ml}$ of the aliquot was transferred to a 15-mL dSPE tube containing 900 mg MgSO4, 300 mg PSA and 150 mg ChloroFiltr ${ }^{\circledR}$. Samples were then vortexed for $30 \mathrm{~s}$ and centrifuged at $8000 \mathrm{rpm}$ for $2 \mathrm{~min}$. An aliquot of $9 \mathrm{ml}$ was diluted in $90 \mathrm{ml}$ of distilled deionized water and passed through a $200 \mathrm{mg}$ HLB (Waters Corporation, Milford, MA) solid phase extraction cartridge. HLB cartridges were eluted with $5 \mathrm{ml}$ of methanol and the extract was evaporated at room temperature under a continuous nitrogen flow to $100 \mu \mathrm{l}$. The extract was fortified with $60 \mathrm{ng}$ internal standards and reconstituted to $500 \mu \mathrm{l}$ with water/methanol mixture (80:20) and filtered using a $0.45 \mu \mathrm{m}$ Mini-UniPrep Syringeless Filter. The final extract was analyzed by HPLC-MS/MS.

\subsection{HPLC-MS/MS analysis}

For HPLC-MS/MS analysis, a Quattro Micro tandem quadrupole mass spectrometer with atmospheric pressure chemical ionization (APCI) source system was used (Waters, Milford MA). An end-capped 
BetaBasic $\mathrm{C}_{18}$ reverse phase HPLC column $(250 \times 2 \mathrm{~mm})$ was used for the chromatographic separation. The injected sample volume was 50 $\mu \mathrm{L}$. The mobile phases consisted of A) $0.15 \%$ formic acid in water/ methanol (97:3) and B) 0.15\% formic acid in methanol/water (97:3); at a constant temperature of $50^{\circ} \mathrm{C}$ and a flow rate of $0.3 \mathrm{ml} / \mathrm{min}$. The gradient of mobile phases was $5 \% \mathrm{~A}$ ) from 0 to $1 \mathrm{~min}, 50 \% \mathrm{~A}$ ) from 1 to $3 \mathrm{~min}, 65 \%-75 \%$ A) from 3 to $10 \mathrm{~min}, 100 \%$ A) from 10 to $15 \mathrm{~min}$ and back to $5 \% \mathrm{~A}$ ) from 15 to $20 \mathrm{~min}$. For the mass spectrometry, the ionization of the analytes was performed with a positive ion mode atmospheric pressure chemical ionization (APCI). A pseudo-molecular ion $[\mathrm{M}+\mathrm{H}]^{+}$was selected as the parent ion for fragmentation, and the corresponding fragment ion(s) were selected for identification and quantitation of the neonicotinoids. Ionization and collision energies were optimized based on procedures described by the instrument manufacturer.

Method detection limits (MDLs) for each analyte were conservatively estimated by replicate analysis of seven aliquots of soybean plant material spiked with $(60 \mathrm{ng} / \mathrm{g})$ of each analyte in $10 \mathrm{~g}$ of uncontaminated plant material. MDLs were calculated based on the standard deviation of the 7 replicate samples $(S)$ multiplied by the Student's " $t$ " for the $99 \%$ confidence level with $n-1$ (6) degrees of freedom (EPA, 2016). Non-detection of residues was assumed when the values were equivalent to $0.0 \mathrm{ng} / \mathrm{g}$. Trace concentration levels of neonicotinoids were included in further analyses as the values below the MDL but above the instrument detection limit IDL. IDLs were determined by multiplying the standard deviation in response from replicate $50 \mu \mathrm{L}$ injections of the lowest calibration standard ( $5 \mathrm{pg} / \mathrm{uL}$ ) by three $(3 \times$ std deviation). The final average concentration of analyte for each treatment included all values obtained in the four replications during both years of study, including both trace concentrations and zero values.

\subsection{Statistical analysis}

Analyte residues from flowers and leaves were analyzed using a generalized linear mixed model with a normal distribution to compare the concentration levels among treatments. The model used the effect of the location nested in years as a fixed variable because different fields were evaluated in each year. The treatments (control and two seed treatments) and each analyte (thiamethoxam, clothianidin, 
and mefenoxam) were also used as fixed variables in the model taking into consideration the possible interaction of the analytes and treatments with the location nested in year. If the treatment_analyte interaction was significant, simple effect comparisons of the treatment by analyte were determined by Fisher's least significant difference $(P<$ 0.05). The analysis for this study was generated using SAS/STAT software version 9.1.3 (SAS Institute Inc, Cary NC).

\section{Results}

\subsection{Method recoveries and detection limits}

Instrument detection limits (IDL), method detection limits (MDL $=\mathrm{st}_{\mathrm{n}}$ ${ }_{1}$ ) statistically estimated from the standard deviation of concentrations measured in the replicated spiked samples, and recovery percentages are reported in Table 1. In general, the accuracy of the method (recovery percentage) and its precision (standard deviation) were acceptable based on Environmental Protection Agency requirements (EPA, 2016). Recoveries from all analytes ranged from 90 to $110 \%$ with relative standard deviations of $<25 \%$ (Table 1 ). In general, thiamethoxam exhibited higher variability in its detection across samples (data not shown).

Table 1. Instrument recoveries and detection limits for the neonicotinoids thiamethoxam and clothianidin and the fungicide mefenoxam using a HPLC-MS/MS analysis with a Quattro Micro tandem quadrupole mass spectrometer with atmospheric pressure chemical ionization $(\mathrm{APCl})$ source system.

\begin{tabular}{llll} 
Analyte & $\begin{array}{l}\text { Instrument detection } \\
\text { limit (IDL) }(\mathrm{pg})^{\mathrm{a}}\end{array}$ & $\begin{array}{l}\text { Method detection } \\
\text { limit }(\mathrm{MDL})(\mathrm{ng} / \mathrm{g})^{\mathrm{b}}\end{array}$ & $\begin{array}{l}\text { Recovery } \\
\%^{\mathrm{b}}\end{array}$ \\
\hline Clothianidin & 113.1 & 1.12 & 99.96 \\
Thiamethoxam & 199.0 & 4.92 & 110.77 \\
Mefenoxam & 23.1 & 0.55 & 80.83
\end{tabular}

a. Determined by multiplying the standard deviation in response from seven replicate 50 $\mu \mathrm{L}$ injections of the lowest calibration standard ( $5 \mathrm{pg} / \mathrm{uL}$ ) by three ( 3 x std deviation). Reported as on-column mass (pg) injected.

b. Method recoveries and detection limits for neonicotinoids in soybean plant tissue using QuEcChERS methodology. MDLs were calculated based on the standard deviation of the 7 replicate samples (S) multiplied by the Student's " $t$ " for the $99 \%$ confidence level with $\mathrm{n}^{-1}(6)$ degrees of freedom (EPA, 2016). 


\subsection{Thiamethoxam and mefenoxam in soybean flowers}

The concentration of soybean flower analytes in each treatment were not significantly different between locations within years $(F=0.75$; df 4,57; $P=0.564)$. Similarly, the overall trace levels of analytes were not significantly different between locations within years $(F=2.16$; $\mathrm{df}=4,57 ; \mathrm{P}=0.085)$. Results of statistical analyses for all fixed effects are included in Table S1. Mean concentrations of thiamethoxam, clothianidin and mefenoxam in soybean flowers were below the MDL for all treatments (MDLs: clothianidin: $1.1 \mathrm{ng} / \mathrm{g}$, thiamethoxam: 4.9 $\mathrm{ng} / \mathrm{g}$, mefenoxam: $0.5 \mathrm{ng} / \mathrm{g}$ ). However, trace levels of contaminants (i.e., above the IDL but below the MDL) were detected in flowers from plants grown from treated but not untreated seeds, and significant treatment $(\mathrm{F}=3.81 ; \mathrm{df}=2,57 ; \mathrm{P}<0.05)$, analyte $(\mathrm{F}=6.84 ; \mathrm{df}=$ $2,57 ; P<0.05)$, and interaction effects between analyte and treatment $(F=16.51 ; d f=4,57 ; P<0.05)$ were observed. Significantly higher $(P<0.05)$ trace levels of thiamethoxam were observed in both seed treatments (thiamethoxam alone and thiamethoxam with mefenoxam) relative to untreated seeds (Fig. 1; results of statistical analyses for all simple effect comparisons are reported in Table S2). For the control

Supplemental Table S1. Statistical analysis for the analyte concentration in soybean flowers using a generalized linear based model.

\begin{tabular}{lrrrr} 
Effect & Num DF & Den DF & F Value & $\operatorname{Pr}>F$ \\
\hline Treatment & 2 & 57 & 3.81 & 0.0279 \\
Analyte & 2 & 57 & 6.84 & 0.0022 \\
Treatment*Analyte & 4 & 57 & 16.51 & $<.0001$ \\
Treatment $^{\star}$ location(year) & 4 & 57 & 0.75 & 0.564 \\
Analyte $^{*}$ ocation(year) & 4 & 57 & 2.16 & 0.085 \\
Treatment $^{\star}$ Analyte ${ }^{\star}$ location(year) & 8 & 57 & 1.64 & 0.1342 \\
\hline
\end{tabular}

Supplemental Table S2. Simple effect comparisons of Trt*Analyte in flowers. Least squares means comparison by analyte. Significant differences $P<0.05$.

\begin{tabular}{lrrr} 
Simple effect level by analyte & Trt & Trt & P-value \\
\hline Clothianidin & Control & Mixture & 0.2199 \\
Clothianidin & Control & Thiamethoxam & 0.3061 \\
Clothianidin & Mixture & Thiamethoxam & 0.9183 \\
Mefenoxam & Control & Mixture & 0.7571 \\
Mefenoxam & Control & Thiamethoxam & 0.3878 \\
Mefenoxam & Mixture & Thiamethoxam & 0.1554 \\
Thiamethoxam & Control & Mixture & $<.0001$ \\
Thiamethoxam & Control & Thiamethoxam & 0.0156 \\
Thiamethoxam & Mixture & Thiamethoxam & 0.3514 \\
\hline
\end{tabular}




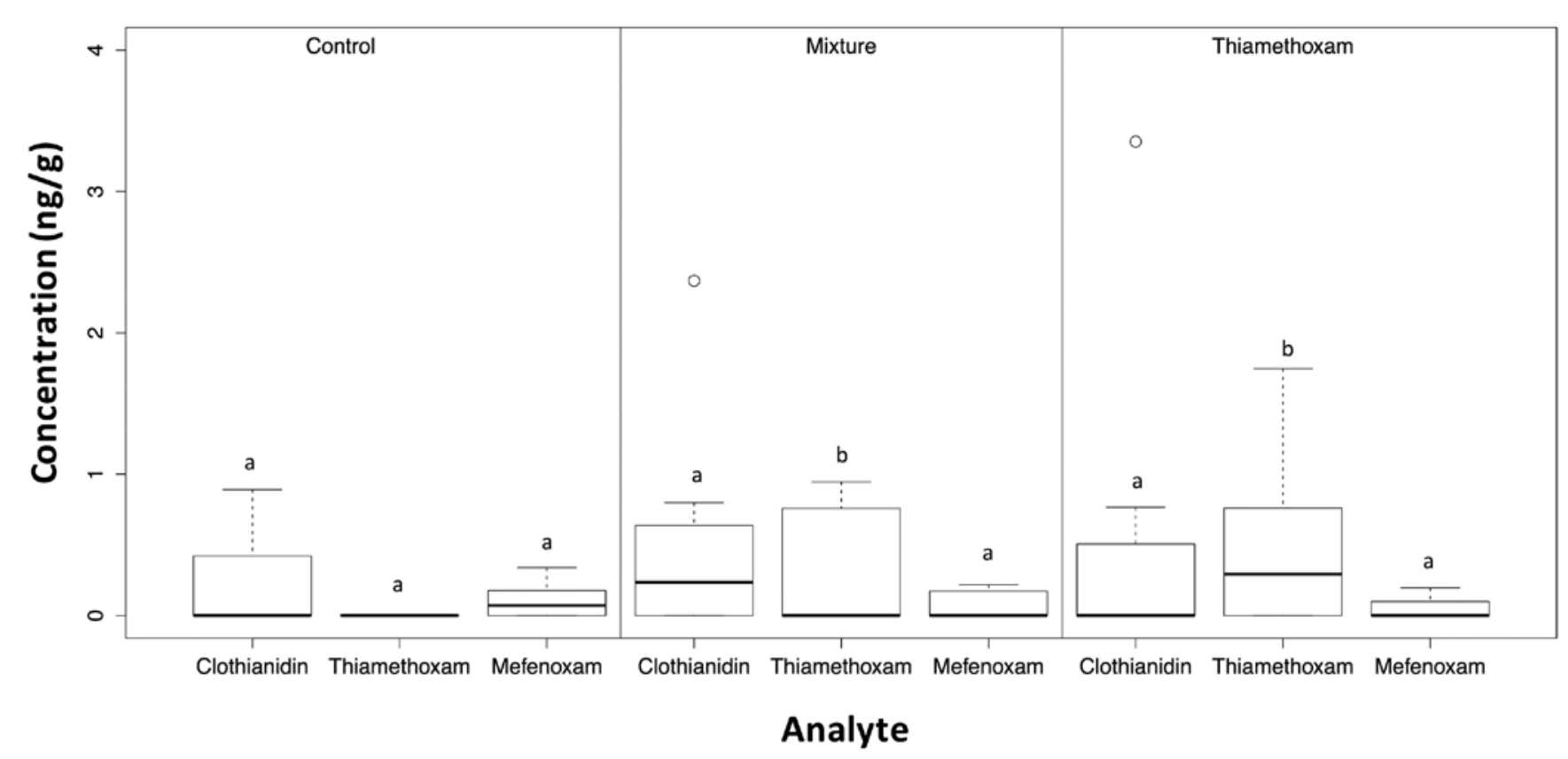

Fig. 1. Concentration of thiamethoxam, clothianidin and mefenoxam analytes detected in soybean flowers. Treatments correspond to: Control = untreated seeds; Mixture $=$ combination of thiamethoxam and mefenoxam seed treatment and Thiamethoxam = thiamethoxam treated seeds. Mean comparisons were conducted for each analyte Clothianidin, Thiamethoxam and Mefenoxam between treatments: Control vs Mixture, Control vs Thiamethoxam, Mixture vs Thiamethoxam. Simple effect comparisons of the treatment by analyte were determined by Fisher's least significant difference $(P<0.05)$

treatment, thiamethoxam concentrations were below limits of detection (both MDL and IDL) with all values considered to be zero. Traces of thiamethoxam in flowers from the two seed treatments (thiamethoxam alone and thiamethoxam with mefenoxam) were not significantly different from each other (Fig. 1).

No significant differences were detected for thiamethoxam's metabolite clothianidin in flowers from seed treatments compared to the flowers in plants from untreated seeds (Fig. 1; Table S2). In general, there was high variability in trace levels of clothianidin in the flowers from seed treatments, which may have obscured differences (Fig. 1). Concentrations of mefenoxam were lower than the neonicotinoid analytes with averages close to zero in both treated and untreated seeds (Fig. 1). 


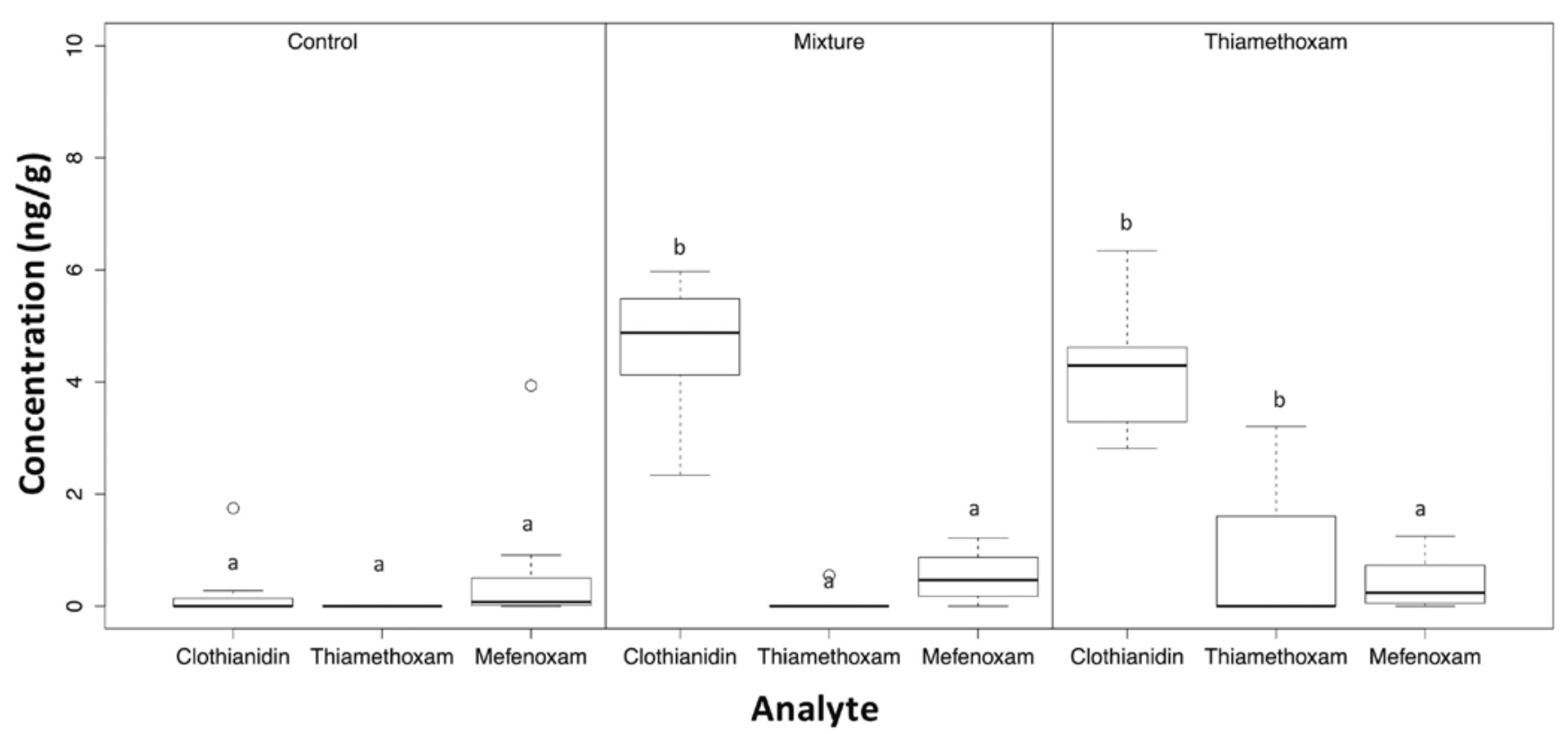

Fig. 2. Concentration of thiamethoxam, clothianidin and mefenoxam analytes detected in soybean leaves. Treatments correspond to: Control = untreated seeds; Mixture $=$ combination of thiamethoxam and mefenoxam seed treatment; and Thiamethoxam $=$ thiamethoxam treated seeds. Simple effect comparisons (Control vs Mixture, Control vs Thiamethoxam, Mixture vs Thiamethoxam) of treatment means were determined by Fisher's least significant difference $(P<0.05)$.

\subsection{Thiamethoxam and mefenoxam in early reproductive stage soy- bean leaves}

Neonicotinoid and mefenoxam residues in soybean leaves at 35-37 DAP are shown in Fig. 2 with clothianidin concentrations for both the thiamethoxam only and thiamethoxam/mefenoxam seed treatments above the MDL (results of statistical analyses for all fixed effects are included in Table S3). There were no significant differences in the concentration of the analytes in the different treatments across location within years $(F=0.68 ; d f=4,48 ; P=0.6084)$. The concentrations of analytes in treated and untreated soybean leaves were significantly different $(F=18.19 ; d f=2,48 ; P<0.0001)$ (Fig. 2), and significantly higher concentrations of clothianidin were found in plants with both seed treatments relative to the control (results of statistical analyses for all simple effect comparisons are included in Table S4; Fig. 2). The concentration of thiamethoxam in leaves from the seed treatments 
Supplemental Table S3. Statistical analysis for the analyte concentration in soybean leaves using a generalized linear based model.

\begin{tabular}{lrrrr} 
Effect & Num DF & Den DF & F Value & Pr $>F$ \\
\hline Treatment & 2 & 48 & 18.19 & $<.0001$ \\
Analyte & 2 & 48 & 18.86 & $<.0001$ \\
Treatment*Analyte & 4 & 48 & 6.63 & 0.0002 \\
Year & 1 & 48 & 0.03 & 0.8726 \\
Treatment*Year & 2 & 48 & 2.48 & 0.0946 \\
Year*Analyte $^{*}$ & 2 & 48 & 2.16 & 0.0802 \\
Treatment*Year*Analyte & 4 & 48 & 0.68 & 0.6084 \\
\hline
\end{tabular}

Supplemental Table S4. Simple effect comparisons of Trt*Analyte in Leaves. Least squares means comparison by analyte. Significant differences $\mathrm{P}<0.05$.

\begin{tabular}{llll} 
Simple effect level by analyte & Trt & Trt & P-value \\
\hline Clothianidin & Control & Mixture & $<.0001$ \\
Clothianidin & Control & Thiamethoxam & $<.0001$ \\
Clothianidin & Mixture & Thiamethoxam & 0.4107 \\
Mefenoxam & Control & Mixture & 0.7926 \\
Mefenoxam & Control & Thiamethoxam & 0.6779 \\
Mefenoxam & Mixture & Thiamethoxam & 0.8715 \\
Thiamethoxam & Control & Mixture & 0.945 \\
Thiamethoxam & Control & Thiamethoxam & 0.0326 \\
Thiamethoxam & Mixture & Thiamethoxam & 0.0341 \\
\hline
\end{tabular}

was not significantly different from the control. Clothianidin was the predominant analyte and was routinely detected at approximately 5 $\mathrm{ng} / \mathrm{g}$ (Fig. 2). Levels of clothianidin in leaves from the thiamethoxammefenoxam and thiamethoxam-only seed treatments were significantly higher $(P<0.05)$ than that of the control, but not significantly different from one another (Fig. 2). The concentration of clothianidin in the control treatment was below the MDL and close to zero for all the analytes (Fig. 2). Both thiamethoxam and clothianidin have been reported from leaves at early vegetative stages (V2) at $151 \mathrm{ng} / \mathrm{g}$ and $5.64 \mathrm{ng} / \mathrm{g}$ respectively (Tietjen et al., 2017) indicating that thiamethoxam is metabolized through time with only its metabolite, clothianidin, detectable $\sim 37$ days after planting.

Concentrations of mefenoxam in leaves were not significantly different between the treatments and the control with values below the MDL for all the treatments (Fig. 2). In leaves from V2 soybean, mefenoxam exhibited a concentration of $2.69 \mathrm{ng} / \mathrm{g}$, confirming that the translocation of mefenoxam to foliage occurs at very low rates. 
These results suggest that the concentration detected in leaves is low and may not have a significant fungicidal impact beyond seed germination, considering that the effective concentration $\left(E_{50}\right)$ of this compound against pathogens such as Phytophtora spp is $\sim 500 \mathrm{ng} / \mathrm{g}$ (Parra and Ristaino, 2001).

\section{Discussion}

Soybean is one of the largest crops in the U.S producing more than a half million flowers per hectare that potentially serve as pollen, nectar, and water resources for pollinators and other beneficial insects (Gill and O'Neal, 2015). Thus, the identification and quantification of pesticide residues in soybean flowers resulting from seed treatments are key to estimating the exposure of beneficial insects to these residues. In the present study, residues of thiamethoxam and its metabolite clothianidin in soybean flowers were either below detection limits or detected only as traces with mean concentrations close to zero or below the MDL. Similar results have been reported for residues of neonicotinoids in soybean flowers in the southern United States (Stewart et al., 2014). These authors reported either non-detection or only traces of thiamethoxam and clothianidin $(<1 \mathrm{ng} / \mathrm{g}$ ) in soybean flowers from plants grown from treated seed at a rate of $0.05 \mathrm{mg}$ of a.i. per seed. Although the seed treatment rate was higher $(0.075 \mathrm{mg}$ a.i.) in the current study, residues of neonicotinoids were similarly low or absent from floral tissue.

Low concentrations of neonicotinoids and other systemic pesticides from seed treatments in soybean floral tissue may be associated with the mechanisms of water movement in the soybean plants to flowers. Residues of neonicotinoids may arrive to the different floral tissues through the movement of water from the xylem, phloem, or both (Bonmatin et al., 2015). In flowers from some angiosperm species, water potential in floral tissues can be lower than the rest of the plant; therefore, water would move to floral tissues mainly via xylem (Roddy et al., 2016). In contrast, in eudicot flowers such as soybean, the water potential in floral structures can be higher than the rest of the plant in which water moves to flowers mainly via phloem (Roddy et al., 2016). Rates of water flux from the phloem is lower compared to xylem (Roddy et al., 2016). As neonicotinoids move mainly via xylem 
(Jeschke et al., 2011), lower concentrations in floral structures would be expected if water is coming mainly from the phloem. If soybean flowers are obtaining water mostly from the phloem, it is likely that concentrations of neonicotinoids in these reproductive structures will be low.

Although residues of thiamethoxam and its toxic metabolite, clothianidin were identified as traces or undetect in floral tissue, clothianidin remained detectable at 35-37 DAP at $5 \mathrm{ng} / \mathrm{g}$ in the leaves while the parent compound, thiamethoxam, was not detected or detected below the MDL. As the concentration of neonicotinoids decreases with plant growth, it is possible that at early reproductive stages, only the metabolites of parent compounds remain in the plant. Similar results have been reported for thiamethoxam seed treatments in sunflowers where clothianidin remained detectable in leaves during flowering, but not thiamethoxam (Bredeson and Lundgren, 2015).

Traces of neonicotinoids in plant tissues are potentially influenced by the nature of seed treatment which can be applied as mixtures or as single pesticide seed treatments. In this study, we found that there were significantly lower levels of thiamethoxam in leaves from the mixture treatment compared to the plants treated with the insecticide alone. Moreover, the concentrations of clothianidin were numerically higher, although not significantly different between the mixture treatment and the treatment with thiamethoxam only. Because mixture treatments can improve plant growth (Gaspar et al., 2015), final concentrations of neonicotinoids may be lower in plants with faster growth rates, which usually occurs with mixture seed treatments. The concentration of neonicotinoids decreases as plant growth increases (Jeschke et al., 2011). Analyses comparing the insecticide alone and in the mixture treatments of fungicides and other plant growth additives at mid-vegetative stages may help elucidate the effect of multiple products in seed treatments on the fate of neonicotinoids in plant tissues.

Based on the results of our study, seed-treatment residues of neonicotinoid insecticides in early reproductive soybean flowers are unlikely to cause acute toxic effects to target and non-target insects. The concentrations of thiamethoxam and its active metabolite, clothianidin, in floral tissues of a number of different plant species have been reported between 0.1 and 7 ng/g (Krupke et al., 2012; Stewart et al., 2014; Xu et al., 2016). These concentrations are below the acute toxic 
effects $\left(\mathrm{LD}_{50}=4-7.5 \mathrm{ng} / \mathrm{bee}\right)$ or chronic toxic effects $\left(L C_{50}\right.$ after 6 days of exposure $=1760 \mu \mathrm{g} / \mathrm{L}$ ) in honey bees under laboratory conditions (Johnson, 2015). However, sub-lethal effects in relation to trace concentrations of neonicotinoids in floral tissues require further investigation especially given recent reports of adverse effects from chronic exposure to neonicotinoids from crop plants (Tsvetkov et al., 2017).

Acute and chronic toxicity are also unlikely for both non-target and target insects that feed on soybean leaves. For example, the acute $\mathrm{LC}_{50}$ for the predator Orius insidiosus Say was estimated to be 767 $\mathrm{ng} / \mathrm{g}$, which far exceeds the concentrations found in leaves reported in the present study (Camargo et al., 2017). For pest insects that arrive in soybean fields at late vegetative and early reproductive stages such as soybean aphid and the first generation of bean leaf beetle, Cerotoma trifurcate (Forster), $\mathrm{LC}_{50}$ after chronic exposure to thiamethoxam in leaf tissue has been estimated at $51.31 \mathrm{ng} / \mathrm{g}$ (Ribeiro et al., 2018) and $2532.67 \mathrm{ng} / \mathrm{g}$ respectively (Tietjen et al., 2017) based on the concentration of cut leaves maintained in a solution of thiamethoxam. These lethal concentrations exceed the residue levels reported in the present study suggesting that efficacy from thiamethoxam to control these pests may be compromised during later stages of soybean development.

Concentrations of mefoxam were generally lower than neonicotinoid concentrations and below the MDL or not detected. Therefore, translocation of mefenoxam to flowers from treated seeds at the rate used in this study $(0.011 \mathrm{mg}$ of a.i. per seed) appears to pose minimal risk to beneficial insects. In addition, mefenoxam was not detected in soybean leaves at early reproductive stages (37 DAP), and at low concentration levels $(2.69 \mathrm{ng} / \mathrm{g})$ at early vegetative stages or 18 DAP. These results support the hypothesis of reduced movement of mefenoxam from treated seeds into the plant vegetative and floral tissue. Gupta et al. (1985) reported that the stereoisomer of mefenoxam, metalaxyl, remained in the cotyledons with only a small percentage moving to leaves and stems of soybean plants. The small percentage of mefenoxam recovered in plant tissue in this study indicates that the fungicide likely remained in the root tissue and cotyledons or diffused into the soil.

The standardization of methods that allow the analysis of parent compounds and metabolites in complex matrixes is crucial for the proper assessment of exposure of neonicotinoids to pollinators and 
other nontarget organisms through residues in plant material. For this study, it is important to consider differences in the detection limits between thiamethoxam and clothianidin. Recovery of thiamethoxam is adversely affected by the matrix components from plant material, while high recovery rates (90-100\%) of clothianidin in complex matrices has been reported (Xie et al., 2011). One of the main difficulties in accurately estimating the fate of neonicotinoids in the environment is the variability in the calculation of the limits of detection (LOD), limits of quantification (LOQ), method detection limit (MDL), and efficiency of the analytical methods used. LOD, LOQ, and MDL are commonly used to describe the smallest concentration of an analyte that can be measured through a given analytical procedure. The calculation of these values can be developed through multiple statistical procedures affecting the interpretation of concentrations found through the analytical methods. Information on how the methods of detection limits are calculated is critical to understanding the capability and limitations of the information on residues of neonicotinoids reported and the accuracy of the values obtained through the multiple analytical methods that have been reported. However, few studies on the environmental fate of neonicotinoids report the methods to estimate these values. Lack of this information compromises the accuracy of the values, the efficiency of the analytical procedure and undermines estimates of environmental risk.

\section{Conclusions}

Results of this study provide increased understanding of neonicotinoids exposure levels in soybean flowers and leaves at R1 to early R2 ( 37 DAP) when the majority of target and non-target insects arrive in soybean fields. While residues were consistently detected in leaves, the concentrations of thiamethoxam and its metabolite clothianidin were low or not detected in both reproductive tissues and leaves. Thus, it is unlikely that residues from neonicotinoids at reproductive stages in soybean after seed treatment are adversely affecting either pests or beneficial insects. However, the potential for sublethal effects under field relevant conditions of exposure requires further investigation. In addition, increased standardization 
of methods for assessing detection limits should be encouraged across studies so that more accurate assessment of field exposures can be achieved.

The use of neonicotinoid seed treatments on soybean in the North Central Region of the U.S is intended to protect plants from pests such as soybean aphid and bean leaf beetle. However, these seed treatments may have limited effect if their concentration is too low when the pests arrive. There have not been detailed studies that document the actual concentration of neonicotinoids in soybean at the time of arrival of soybean aphid. This study provides crucial baseline information of the negligible levels of thiamethoxam at early reproductive stages under field conditions.

Declaration of interest - All authors stated that they adhered to the policies and ethics of Crop Protection.

Acknowledgments - We would like to thank Dr. Gary L. Hein for the critical reading and suggestions for improving previous versions of this manuscript. We also would like to thank Nicholas Arneson and Kyle Broderick from the Plant Pathology Department at the University of Nebraska-Lincoln for their support in planting and maintenance of field plots. First author was partially funded by the Colombian Institute of Science and Technology- COLCIENCIAS and the University of NebraskaLincoln. This research did not receive any specific grant from funding agencies in the public, commercial, or not-for-profit sectors.

\section{References}

Bonmatin, J.M., Giorio, C., Girolami, V., Goulson, D., Kreutzweiser, D.P., Krupke, C., Liess, M., Long, E., Marzaro, M., Mitchell, E.A., Noome, D.A., Simon-Delso, N., Tapparo, A., 2015. Environmental fate and exposure; neonicotinoids and fipronil. Environ. Sci. Pollut. Res. Int. 22, 35-67.

Bredeson, M.M., Lundgren, J.G., 2015. Thiamethoxam seed treatments have no impact on pest numbers or yield in cultivated sunflowers. J. Econ. Entomol. $108,2665-2671$.

Camargo, C., Hunt, T.E., Giesler, L.J., Siegfried, B.D., 2017. Thiamethoxam toxicity and effects on consumption behavior in Orius insidiosus (Hemiptera: Anthocoridae) on Soybean. Environ. Entomol. 46, 693-699.

Cox, W.J., Cherney, J.H., 2011. Location, variety, and seeding rate interactions with soybean seed-applied insecticide/fungicides. Agron. J. 103, 1366-1371.

Cox, W.J., Shields, E., Cherney, J.H., 2008. Planting date and seed treatment effects on soybean in the northeastern United States. Agron. J. 100, 1662-1665. 
Douglas, M.R., Tooker, J.F., 2015. Large-scale deployment of seed treatments has driven rapid increase in use of neonicotinoid insecticides and preemptive pest management in U.S. field crops. Environ. Sci. Technol. 49, 5088-5097.

EPA, 2016. Definition and Procedure for the Determination of the Method Detection Limit. Revision 2. Office of Water EPA 821-R-16-006. https://www.epa.gov/cwamethods

Gaspar, A.P., Mitchell, P.D., Conley, S.P., 2015. Economic risk and profitability of soybean fungicide and insecticide seed treatments at reduced seeding rates. Crop Sci. 55, 924-933.

Gill, K.A., O'Neal, M.E., 2015. Survey of soybean Insect pollinators: community identification and sampling method analysis. Environ. Entomol. 44, 488-498.

Girolami, V., Mazzon, L., Squartini, A., Mori, N., Marzaro, M., Di Bernardo, A., Greatti, M., Giorio, C., Tapparo, A., 2009. Translocation of neonicotinoid insecticides from coated seeds to seedling guttation drops: a novel way of intoxication for bees. J. Econ. Entomol. 102, 1808-1815.

Gupta, J.P.E.J.W., Eckert, J.W., Zaki, A.I., 1985. Translocation of metalaxyl in soybean plants and control of stem rot caused by Phytophtora megasperma f.sp. glycinea. Phytopathology 75, 865-869.

Jeschke, P., Nauen, R., Schindler, M., Elbert, A., 2011. Overview of the status and global strategy for neonicotinoids. J. Agric. Food Chem. 59, 2897-2908.

Johnson, R.M., 2015. Honey bee toxicology. Annu. Rev. Entomol. 60, 415-434.

Krupke, C.H., Hunt, G.J., Eitzer, B.D., Andino, G., Given, K., 2012. Multiple routes of pesticide exposure for honey bees living near agricultural fields. PLoS One 7, e29268.

Magalhaes, L.C., Hunt, T.E., Siegfried, B.D., 2009. Efficacy of neonicotinoid seed treatments to reduce soybean aphid populations under field and controlled conditions in Nebraska. J. Econ. Entomol. 102, 187-195.

Maienfisch, P., Angst, M., Brandl, F., Fischer, W., Hofer, D., Kayser, H., Kobel, W., Rindlisbacher, A., Senn, R., Steinemann, A., Widmer, H., 2001. Chemistry and biology of thiamethoxam: a second generation neonicotinoid. Pest Manag. Sci. 57, 906-913.

Monkiedje, A., Spiteller, M., 2005. Degradation of metalaxyl and mefenoxam and effects on the microbiological properties of tropical and temperate soils. Int. J. Environ. Res. Publ. Health 2, 272-285.

Monkiedje, A., Spiteller, M., Maniepi, S.J.N., Sukul, P., 2007. Influence of metalaxyland mefenoxam-based fungicides on chemical and biochemical attributes of soil quality under field conditions in a southern humid forest zone of Cameroon. Soil Biol. Biochem. 39, 836-842.

Parra, G., Ristaino, J.B., 2001. Resistance to mefenoxam and metalaxyl among field isolates of Phytophthora capsici causing Phytophthora blight of bell pepper. Plant Dis. 85, 1069-1075.

Pedersen, P., Elbert, B., 2004. Soybean Growth and Development. lowa State University, University Extension Ames, IA.

Pedersen, P., Lauer, J.G., 2004. Soybean growth and development in various management systems and planting dates. Crop Sci. 44, 508-515. 
Pisa, L.W., Amaral-Rogers, V., Belzunces, L.P., Bonmatin, J.M., Downs, C.A., Goulson, D., Kreutzweiser, D.P., Krupke, C., Liess, M., McField, M., Morrissey, C.A., Noome, D.A., Settele, J., Simon-Delso, N., Stark, J.D., Van der Sluijs, J.P., Van Dyck, H., Wiemers, M., 2015. Effects of neonicotinoids and fipronil on non-target invertebrates. Environ. Sci. Pollut. Res. Int. 22, 68-102.

Pohorecka, K., Skubida, P., Miszczak, A., Semkiw, P., Sikorski, P., Zagibajło, K., Teper, D., Kołtowski, Z., Skubida, M., Zdańska, D., Bober, A., 2012. Residues of neonicotinoid insecticides in bee collected plant materials from oilseed rape crops and their effect on bee colonies. J. Apicult. Sci. 56.

Ribeiro, M.G.P.d.M., Hunt, T.E., Siegfried, B.D., 2018. Acute-contact and chronicsystemic in vivo bioassays: regional monitoring of susceptibility to thiamethoxam in soybean aphid (Hemiptera: Aphididae) populations from the North Central United States. J. Econ. Entomol. 111, 337-347.

Roddy, A., Brodersen, C.R., Dawson, T.E., 2016. Hydraulic conductance and the maintenance of water balance in flowers. Plant Cell Environ. 39, 2123-2132. Seagraves, M.P., Lundgren, J.G., 2012. Effects of neonicitinoid seed treatments on soybean aphid and its natural enemies. J. Pest. Sci. 85, 125-132.

Simon-Delso, N., Amaral-Rogers, V., Belzunces, L.P., Bonmatin, J.M., Chagnon, M., Downs, C., Furlan, L., Gibbons, D.W., Giorio, C., Girolami, V., Goulson, D., Kreutzweiser, D.P., Krupke, C.H., Liess, M., Long, E., McField, M., Mineau, P., Mitchell, E.A., Morrissey, C.A., Noome, D.A., Pisa, L., Settele, J., Stark, J.D., Tapparo, A., Van Dyck, H., Van Praagh, J., Van der Sluijs, J.P., Whitehorn, P.R., Wiemers, M., 2015. Systemic insecticides (neonicotinoids and fipronil): trends, uses, mode of action and metabolites. Environ. Sci. Pollut. Res. Int. 22, 5-34.

Singh, U.S., Tripathi, R.K., Kumar, J., Dwivedi, T.S., 1986. Uptake, translocation, distribution and persistence of 14C-metalaxyl in pearl millet (Pennisetum americanum) [L.] Leeke)1. J. Phytopathol. (Berl.) 117, 122-135.

Stewart, S.D., Lorenz, G.M., Catchot, A.L., Gore, J., Cook, D., Skinner, J., Mueller, T.C., Johnson, D.R., Zawislak, J., Barber, J., 2014. Potential exposure of pollinators to neonicotinoid insecticides from the use of insecticide seed treatments in the Mid- Southern United States. Environ. Sci. Technol. 48, 9762-9769.

Stoner, K.A., Eitzer, B.D., 2012. Movement of soil-applied imidacloprid and thiamethoxam into nectar and pollen of squash (Cucurbita pepo). PLoS One 7, e39114. Sukul, P.S.,M., 2000. Metalaxyl: persistence, degradation, metabolism, and analytical methods. Rev. Environ. Contam. Toxicol. 164, 1-26.

Tietjen, C.L., Hunt, T.E., Snow, D.D., Cassada, D.A., Siegfried, B.D., 2017. Method development for monitoring bean leaf beetle, Cerotoma trifurcata (Forster) (Coleoptera: chrysomelidae), susceptibility to thiamethoxam seed treatments on soybeans. J. Agric. Urban Entomol. 33, 32-43.

Triantafyllidis, V., Hela, D., Papadaki, M., Bilalis, D., Konstantinou, I., 2012. Evaluation of mobility and dissipation of mefenoxam and pendimethalin by application of CSTR model and field experiments using bare and tobacco tilled soil columns. Water Air Soil Pollut. 223, 1625-1637.

Tsvetkov, N., Samson-Robert, O., Sood, K., Patel, H.S., Malena, D.A., Gajiwala, P.H., Maciukiewicz, P., Fournier, V., Zayed, A., 2017. Chronic exposure to neonicotinoids reduces honey bee health near corn crops. Science 356, 1395-1397. 
van der Sluijs, J.P., Amaral-Rogers, V., Belzunces, L.P., Bijleveld van Lexmond, M.F., Bonmatin, J.M., Chagnon, M., Downs, C.A., Furlan, L., Gibbons, D.W., Giorio, C., Girolami, V., Goulson, D., Kreutzweiser, D.P., Krupke, C., Liess, M., Long, E., McField, M., Mineau, P., Mitchell, E.A., Morrissey, C.A., Noome, D.A., Pisa, L., Settele, J., Simon-Delso, N., Stark, J.D., Tapparo, A., Van Dyck, H., van Praagh, J., Whitehorn, P.R., Wiemers, M., 2015. Conclusions of the worldwide integrated assessment on the risks of neonicotinoids and fipronil to biodiversity and ecosystem functioning. Environ. Sci. Pollut. Res. Int. 22, 148-154.

Wilson, P.C., Whitwell, T., Klaine, S.J., 2001. Metalaxyl toxicity, uptake, and distribution in several ornamental plant species. J. Environ. Qual. 30, 411-417.

Xie, W., Han, C., Qian, Y., Ding, H., Chen, X., Xi, J., 2011. Determination of neonicotinoid pesticides residues in agricultural samples by solid-phase extraction combined with liquid chromatography-tandem mass spectrometry. J. Chromatogr. A 1218, 4426-4433.

Xu, T., Dyer, D.G., McConnell, L.L., Bondarenko, S., Allen, R., Heinemann, O., 2016. Clothianidin in agricultural soils and uptake into corn pollen and canola nectar after multiyear seed treatment applications. Environ. Toxicol. Chem. 35, 311-321. 